\title{
METODOLOGI PEMBELAJARAN ANAK USIA DINI (PAUD)
}

\author{
Oleh: \\ Kandiri \& Mahmudi \\ Universitas Ibrahimy Situbondo \\ kandiri93@gmail.com \\ mahmudibajuri4@gmail.com
}

\begin{abstract}
:
In the implementation of teaching and learning activities, the teacher needs to know the teaching components such as teaching methods because without using methods, teaching and learning activities do not work as expected. Teaching methods as a path to provide opportunities for students in many kinds of lessons, because those are the efforts of the teacher in guiding, directing, or organizing learning in a series of activities that the students learn to accept, understand, respond, possess, master and develop it. Teaching methods are one effective and efficient way that teachers use to convey that subject matter, as well as coaching, direction, learning organizers so that children can experience all kinds of subjects. While there are factors that influence the number of teaching methods are as follows: a) Objectives of various types and functions. b) Students who have varying degrees of maturity, c) Situations of various conditions, d) Facilities that different in quality and quantity, e) Teachers' personality that different in professional abilities.
\end{abstract}

Keywords: Pembelajaran, Anak Usia Dini

\section{A. Kajian Metode Pembelajaran}

Dalam pelaksanaan kegiatan belajar mengajar, seorang guru perlu mengetahui komponen-komponen pengajaran. Diantara komponen yang sangat menunjang pada kegiatan belajar yaitu metode pengajaran. Metode memiliki arti dan patut dipertimbangkan tanpa menggunakan metode maka dalam kegiatan belajar mengajar tidak berjalan sebagaimana yang telah diharapkan.

Metode adalah Istilah yang digunakan untuk menggunakan cara yang paling tepat dan dalam melakukan sesuatu. ${ }^{1}$ Menurut Muhammad Altiyah Al-Abrosy, dikutipkan dari buku karangan Jalaluddin bahawa metode mengajar sebagai jalan yang kita ikuti untuk memberi peluang

1 Ahmad Tafsir, Metodologi Pengajaran Agama Islam, (Bandung: Remaja Restra Karya, 2001). hlm. 9

\begin{tabular}{l|l} 
JURNAL LISAN AL-HAL & 251
\end{tabular} 
pada murid-murid dalam segala macam pelajaran dan mata pelajaran. ${ }^{2}$

Sedangkan menurut Dirjen bin Baga Islam yang dikutipkan dari buku karangan Muhaimin, mengatakan bahwa metode mengajar adalah usaha guru dalam membimbing, mengarahkan, atau mengorganisir belajar dalam satu rangkaian kegiatan penyampaian bahawa pelajaran kepada murid agar menerima, memahami, menanggapi, memiliki, menguasai dan mengembangkannya. ${ }^{3}$

Dari berbagai pendapat diatas dapat disimpulkan bahawa metode mengajar adalah satu cara yang efektif dan etisien yang digunakan guru untuk menyampaikan bahwa materi pelajaran, serta pembinaan, pengarahan, pengorganisir belajar agar anak bisa mengalami segala macam mata pelajaran.

\section{Faktor-Faktor Penyebab Banyaknya Metode Pengajaran}

Menurut Prof. Dr. Winarno Surahmad, MS., berpendapat bahwa faktor-faktor yang mempengaruhi banyaknya metode mengajar adalah sebagai berikut: a) Tujuan yang berbagai jenis dan fungsinya; b) Anak didik yang berbagai tingkat kematangannya; c) Situasi yang berbagai keadaannya; d) Fasilitas yang berbeda kualitas dan kuantitasnya; dan e) Pribadi guru serta kemampuan profesionalnya yang berbeda. ${ }^{4}$

Sedangkan menurut Drs. Imansyah Alipandie di dalam bukunya yang berjudul Didaktik dan Metodik Pendidikan Umum mengatakan bahwa faktor-faktor penyebab banyaknya metode mengajar sebagai berikut :

a). Tujuan yang berbeda pada setiap pelajaran sesuai dengan jenis, fungsi, sifat maupun isi mata pelajaran masing-masing. Misalnya dari segi tujuan dan sifat pelajaran agama yang membicarakan tentang masalah keimanan, tentunya lebih bersifat filosofis daripada pelajaran matematika yang bersifat praktis dan menekankan pada aspek intelektual, karena itu metode digunakan juga berbeda.

b). Perbedaan latar belakang individual anak baik dari segi kehidupan/ketentuan, tingkah usia perkembangan/kematangan, maupun tingkat kemampuan berpikirnya.

2 Jalaluddin Dan Usman Said, Filsafat Pendidikan Islam, (Jakarta: Raja Grafindo Persada 1996), hlm. 52 55.

3 Muhaimin Dkk., Strategi Belajar Mengajar, (Surabaya : Citra Media, 1996), hlm.

4 Winarno Surahmad, Pengantar Penelitian Ilmu Dasar Metode dan Tehnik, (Bandung : Tarsito, 1998), hlm. 76

$252 \mid$ JURNAL LISAN AL-HAL 
c). Perbedaan pribadi dan kemampuan guru masing-masing, misalnya seorang guru yang pandai bercerita disertai mimik, tekanan suara dan gaya, dan lebih berhasil daripada guru lain yang berpembawaan kurang pandai bicara dan akting di muka kelas.

d). Perbedaan situasi dan kondisi dimana pendidikan berlangsung baik berupa lembaga pendidikan yang berbeda, letak geografis maupun sosial kultural, yang kesemuanya ikut menentukan metode yang dipakai oleh guru.

e). Fasilitas yang berbeda baik kualitas maupun kwantitas. Suatu sekolah yang memiliki saranan dan prasarana lengkap berupa gedung tata ruang sekaligus peralatan untuk praktikan, relatif lebih mudah melaksanakan metode demonstrasi dan eksperimen daripada sekolah-sekolah yang serba kekurangan sarana dan prasarana pendidikannya. $^{5}$

\section{Beberapa Metode Pengajaran Anak Usia Dini (PAUD)}

Metode yang digunakan oleh seorang guru merupakan salah satu kunci pokok didalam keberhasilan suatu proses belajar mengajar. Pemilih metode yang digunakan di taman kanak-kanak harus disesuaikan dengan tujuan penguasaan konsep. Berbagai variasi materi, media dan bentuk kegiatan yang akan dilakukan. ${ }^{6}$

Berikut merupakan metode-metode pengajaran yang sesuai dengan karakteristik anak usia TK: bermain, karyawisata, bercakap-cakap, bercerita, demonstrasi, proyek dan pemberian tugas.

Pertama, Metode Bermain. Bagi anak, bermain adalah suatu kegiatan yang serius, namun mengasyikkan. Melalui aktifitas bermaian, bebagai pekerjaannya terwujud. Bermain adalah salah satu aktifitas yang dipilih sendiri oleh anak karena menyenangkan, bukan karena akan memperoleh hadiah atau pujian. Bermain adalah medium dimana si anak mencobakan diri, bukan saja dalam fantasinya tetapi juga benar nyata secara aktif. Bila anak bermain secara bebas, sesuai kemauan2 maupun sesuai kecepatannya sendiri, maka ia melatih kemampuannya.

Dengan memahami arti bermain bagia anak, maka bisa ditarik kesimpulan bahwa bermain adalah suatu kebutuhan bagi anak. Dengan

5 Imansiyah Alipandie, Didaktik Metodik Pendidikan Umum, (Surabaya: Usaha Nasional, 1984), hlm. 73 13

6 Dep. Dik. Nas, Permainan Berhitung di Taman Kanak-Kanak, (Jakarta: 2000), hlm.

\begin{tabular}{l|l} 
JURNAL LISAN AL-HAL & 253
\end{tabular} 
merancang pelajaran tertentu untuk dilakukan sambil bermain, maka anak belajar sesuai dengan tuntutan taraf perkembangannya.

Bermain mempunyai beberapa makna: 1) Bermain dapat mebantu pertumbuhan anak; 2) Bermain memberi kebebasan anak untuk bertindak; 3) Bermain meletakkan dasar perkembangan Bahasa; 4) Bermain mempunyai pengaruh yang unik dalam pembentukan hubungan antar pribadi; 5) Bermain memperluas minat dan pemusatan perhatian.; dan 6) Bermain merupakan cara dinamis untuk belajar. ${ }^{7}$

Kedua, Metode Karyawisata. Karyawisata wisata dalam arti metode mengajar mempunyai arti tersendiri yang berbeda dengan karya wisata dalam arti umum. Karyawisata disini berarti kunjungan keluar kelas dalam rangka belajar. ${ }^{8}$ Bagi anak TK karyawisata berarti memperoleh kesempatan untuk mengobserfasikan, memperoleh informasi, atau mengkaji segala sesuatu secara langsung.

Berkaryawisata mempunyai makna penting bagi perkembangan anak karena dapat membangkitkan minat anak kepada satu hal, dan memperluas perolehan informasi. Juga memperkaya lingkup program kegiatan belajar anak TK yang tidak mungkin dihadirkan di kelas, seperti melihat bermacam-macam hewan, mengamati proses pertumbuhan. Dari karyawisata anak dapat belajar dari pengalaman sendiri dan sekaligus anak dapat melakukan generalisasi berdasarkan sudut pandang mereka. ${ }^{9}$

Ketiga, Metode Bercakap-Cakap. Bercakap-cakap adalah suatu cara penyampaian bahan pengembangan yang dilaksanakan melalui bercakpcakap dalam bentuk tanya jawab antara anak dengan guru atau anak dengan anak. ${ }^{10}$ Bercakap-cakap adalah suatu cara penyampaian bahwa pengembangan anak taman kanak-kanak, karena bercakap-cakap dapat meningkatkan dalam melakukan kegiatan bersama, juga meningkatkan keterampilan menyatakan perasaan. ${ }^{11}$ Oleh karena itu, penggunaan metode bercakap-cakap bagi anak TK terutama, akan membantu perkembangan dimensi sosia, emosi dan kognitif, terutama bahasa.

Keempat, Metode Bercerita. Cerita adalah penerangan yang sangat digemari orang banyak maupun orang dewasa. Oleh karena itu, sudah

7 Conny. R. Semiawan, Belajar dan Pembelajaran Dalam TaraUsia Dini, (Jakarta : Pranhalindo, 2002), hlm. 87

8 Nana Sadjana, Dasar-Dasar Proses Belajar Mengajar, (Bandung : Sinar Baru Algensindo 1995), hlm. 87

${ }_{9}^{9}$ Moeslihaton, Metode Pengajaran di Taman Kanak-Kanak, (Jakarta : Asdi Mahatya, 2004), hlm. 25

10 Permainan Berhitung Ditaman Kanak-Kanak, Op. Cit, hlm. 10

11 Moeslihaton, Metode Pengajaran di Taman Kanak-Kanak., 26

$254 \mid$ JURNAL LISAN AL-HAL 
selayaknya cerita yang diberikan bersifat ringkas dan mempunyai tujuan yang jelas. Kerterlibatan anak terhadap dongeng yang diceritakan akan memberikan suasana yang segar, menarik dan menjadi pengalaman yang unik bagi anak. ${ }^{12}$

Ada bermacam teknik mendongeng antara: membaca langsung dari buku cerita, mengunakan ilustrasi suatu buku sambil meneruskan bercerita, menceritakan dongeng, bercerita menggunakan papan hanel, bercerita melalui permainan peran bercerita dari majalah bergambar, cerita melalui lagu. Bercerita mempunyai makna penting anak bagi perkembangan anak TK karena mealui bercerita kita dapat: Mengkomunikasikan nilai-nilai budaya, Mengkomunikasikan nilai-nilai sosial, Mengkomunikasikan nilai-nilai keagamaan, Menanamkan atas kerja, atas waktu, atas alam, Membantu mengembangkan fantasi anak, Membantu mengembangkan dimensi kognitif anak dan Membantu mengembangkan dimensi bahasa anak.

Kelima, Metode Demonstrasi. Demonstrasi adalah suatu cara untuk untuk mempertunjukkan atau memperagakan suatu obyek atau proses dari suatu kejadian atau peristiwa. ${ }^{13}$ Demonstrasi mempunyai makna penting bagi anak TK antara lain: a) Memperhatikan secara konkorit apa yang dilakukan/ diperagakan; b) Dapat mengkomunikasikan gagasan, konsep, prinsip dengan peragaan; c) Membantu mengembangkan kemampuan mengamati secara teliti dan cermat; d) Membantu mengembangkan kemampuan untuk melakukan segala secara pekerjaan teliti, cermat; dan e) Membantu mengembangkan kemampuan peniruan dan pengenalan secara tepat.

Keenam, Metode Proyek. Metode proyek adalah suatu metode yang digunakan untuk melatih kemampuan anak memecahkan masalah yang dialami anak dalam kehidupan sehari-hari. Cara ini juga dapat mengerahkan anak untuk melakukan kerjasama sepenuh hati. Kerjasama dilaksanakan secara terpadu untuk mencapai tujuan bersama. Kegiatan proyek mempunyai makna penting bagi anak TK antara lain: a) Di dalam kegiatan bersama, anak belajar mengatur diri sendiri untuk bekerja sama dengan teman dalam memecahkan suatu masalah; b) Dalam kegiatan proyek, pengalaman akan sangat bermakna bagi anak. Misalnya penglaman siswa dalam melipat kertas; c) Kegiatan proyek punya dampak dalam pengembangan atas kerja, atas waktu, atas lingkungan; d) Berlatih

12 Imron Rosyidi, Kiat Mendiddk Anak Masa Depan, (Jakarta: Najla Pres, 2003), hlm.

13 Permainan Berhitung di Taman Kanak-Kanak, 14 
untuk berprakarsa dan bertanggung jawab; dan e) Berlatih menyelesaikan tugas yang harus diselesaikan tugas yang harus diselesaikan secara bebas dan kreatif.

Oleh karena itu, metode proyek merupakan salah satu bentuk kegiatan dalam memecahkan masalah bersama yang mempunyai nilai praktis yang sangat penting bagi pengembangan pribadi anak, serta mengembangkan keterampilan menjalani kehidupan sehari-hari. Metode proyek merupakan salah satu metode yang cocok bagi pengembangan terutama dimensi kognitif, social, motorik, kreatif, dan emosional anak TK. 14

Keenam, Metode Pemberian Tugas. Pemberian tugas adalah pemberian kegiatan belajar mengajar dengan memberikan kesempatan kepada anak untuk melaksanakan tugas yang di siapkan oleh guru. ${ }^{13}$ Pemberian tugas mempunyai makna penting bagi anak TK, antara lain: a) Pemberian Tugas secara lisan akan memberi kesempatan kepada anak untuk melatih persepsi pendengaran; b) Pemberian tugas melatih anak untuk memusatkan perhatian dalam jangka waktu tertentu; c) Pemberian Tugas dapat membangun motivasi anak. Pemberian tugas merupakan salah satu metode pengajaran yang memungkinkan anak untuk mengembangan kemampuan bahasa reseptif : kemamapuan mendengar dan menangkap arti, kemampuan kognitif : memperhatikan kemampuan kerja sampai tuntas. ${ }^{14}$

\section{Penggunaan Metode di Taman Kanak-kanak}

Sebagaimana dikemukakan bahwa metode itu merupakan cara yang dalam fungsinya merupakan alat untuk mencapai kegiatan. Sebagai alat untuk mencapai tujuan tidak selamanya berfungsi secara memadai. Oleh karena itu, dalam memilih suatu metode yang akan dipergunakan dalam program kegiatan anak di taman kanak-kanak guru perlu mempunyai alasan yang kuat dan faktor-faktor yang mendukung pemilihan metode tersebut, seperti : karakteristik tujuan kegiatan dan karakteristik anak yang diajar.

Yang dimaksud dengan karakteristik tujuan adalah pengembangan metode dan pengembangan kreatifitas, pengembangan bahasa, pengembangan emosi, pengembangan metode dan pengembangan nilai serta pengembangan sikap dan nilai.

${ }^{14}$ Moeslihaton, Op. Cit., hlm. 28

${ }^{13}$ Permainan Berhitung di Taman Kanak-Kanak, Op. Cit. hlm. 14

${ }^{14}$ Moeslihaton, Metode Pengajaran di Taman Kanak-Kanak., hlm. 29

256 JURNAL LISAN AL-HAL 
Untuk mengembangkan kognisi anak dapat dipergunakan metode yang mampu menggerakkan anak agar menumbuhkan berpikir, menalar, mampu menarik kesimpulan dan mebuat generalisasi. Caranya adalah dengan memahami lingkungan disekitarnya, mengenal orang dan bendabenda yang ada, memahami tubuh dan perasaan mereka sendiri/melatih memahami untuk mengurus diri sendiri. Selain itu melatih anak menggunakan bahasa untuk berhubungan dengan orang lain, dan melakukan apa yang dianggap bernar berdasar nilai yang ada dalam masyarakat.

Guru mengembangkan kreativitas anak, metode-metode yang dipilih adalah metode yang dapat menggesek anak untuk meningkatkan motivasi rasa ingin tahu dan mengembangkan imajinasi.

Metode yang digunakan untuk membantu perkembangan bahasa anak, atau kemampuan berkomunikasi, maka guru memberi kemudahan atau peluang kepada anak dengan sebaik-baiknya. Berbagai peluang itu diantaranya sebagai berikut :

a. Bertutur kata yang baik dengan anak.

b. Mau mendengarkan pembicaraan anak.

c. Mengajak berdialog.

d. Anak dibiasakan untuk bertanya, mengekspresikan keinginannya, menghafalkan dan melantunkan lagu dan puisi. ${ }^{15}$

Guru mengembangkan emosi anak dengan menggunakan metodemetode yang menggerakkan anak untuk mengekspresikan perasaan yang menyenangkan, karena anak usia TK telah memiliki emosi yang lebih luas. Ia telah memiliki perasaan takut, marah, sedih dan jengkel. Sedangkan perkembangan emosinya disebabkan ia telah mampu memahami lingkungan sosialnya, anak muali dapat merasakan apa yang dirasakan oleh orang lain. ${ }^{16}$

Guru untuk mengembangkan kemampuan motorik anak dapat dipergunakan metode-metode yang menjamin anak tidak mengalami cedera, misalnya menyusun balok dan melipat, tangga majemuk, jungkitan, papan peluncur untuk melatih anak menguasai keterampilan motorik halus dan kasar.

Untuk mengembangkan nilai dan sikap anak dapat dipergunakan metode-metode yang memungkin terbentuknya kebiasaan-kebiasaan yang

\footnotetext{
15 Syamsu Yusuf Cn., Psikologi Perkembangan Anak dan Remaja, (Bandung : Remaja Rosdakarya,, 2001), hlm. 170

16 Edy Gustian, Mempersiapkan Anak-anak Masuk Sekolah, (Jakarta : Puspa Swara, 2001), hlm. 22
} 
didasari oleh nilai-nilai agama dan moral Pancasila agar anak dapat menjalani hidup sesuai dengan norma yang dianut oleh masyarakat.

Selain dari tujuan kegiatan karakteristik anak juga ikut menentukan pemilihan metode. Perlu diingat oleh guru bahwa anak kecil itu banyak bergerak dan tidak bisa diam untuk waktu yang lama, mempunyai rasa ingin tahu yang kuat, senang bereksperimen, dan menguji mampu mengeksperimenkan diri secara kreatif, mempunyai imajinasi dan senang berbicara.

Anak pada usia TK itu tidak dapat disuruh duduk diam selama jam kegaitan. Bagi anak TK duduk diam selama jam kegiatan merupakan pekerjaan yang amat berat, anak membutuhkan dan menuntut untuk bergerak yang melibatkan koordinasi otot kasar misalnya merayap, merangkak, berjalan, berlari, melompat, menendang, melempar dan lainlain.

Pada usia TK pengembangan sosial anak sudah tampak jelas, karena mereka sudah mulai aktif berhubungan dengan teman sebayanya. Kematangan penyesuaian sosial anak dan sangat terbantu, apabila anak dimasukkan ke Taman Kanak-kanak (TK) sebagai "jembatan bergaul" merupakan tempat yang memberikan peluang kepada anak untuk belajar memperluas pergaulan sosialnya, dan menaati peraturan (kedisplinan), TK dipandang kontribusi yang baik bagi perkembangan sosial anak. ${ }^{17}$

Anak TK menganggap permainan fantasi adalah hal yang nyata karena mereka belum mampu membedakan dunia khayal dengan realitas yang sebenarnya. ${ }^{18}$ Untuk memenuhi dorongan ingin memahami lingkungan anak TK sering kali berbicara sendiri, bertanya kepada teman atau orang yang ditemuinya. Bagi guru sebagai daya tarik dalam melaksanakan kegiatan sehari-hari. Di samping itu, kita juga dapat mencari topik-ropik yang bisa dijadikan bahan pemecahan masalah yang menarik bagi anak.

Selain tujuan kegiatan dan karakteristik anak TK sedikitnya ada 4 faktor lain yang ikut berpengaruh dalam metode, yakni kegiatan dilakukan di dalam atau di luar kelas, keterampilan yang hendak dikembangkan melalui berbagai kegiatan, tema yang dipilih dalam kegiatan yang tersebut, pola kegiatan itu sendiri.

Keterampilan yang hendak dikembangkan melalui berbagai program kegiatan dapat dibedakan atas pengembangan keterampilan kognitif, bahasa, kreativitas, motorik dan emosi serta perkembangan sikap

17 Moeslihaton, Metode Pengajaran di Taman Kanak-Kanak., hlm. 10

18 Edy Gustian, Mempersiapkan Anak-anak Masuk Sekolah., hlm. 11 
hidup. Untuk mengembangkan berbagai keterampilan itu, dapat kita pilih metode yang paling cocok untuk masing-masing.

Gorden dan Browne mengemukakan tiga macam pola kegiatan yang dapat dipilih guru TK untuk mencapai tujuan kegiatan yaitu, kegiatan yang dilaksanakan dengan pengarahan langsung oleh guru, adalah kegiatan yang kondisi dan kegaiatannya berada dalam jangka waktu tertentu. Kegiatan macam ini mempunyai cirri-ciri anaknya duduk dengan tenang di bangku masing-masing dan memperhatikan apa yang harus dikerjakan sesuai dengan suruhan guru. Selain itu, biasanya anak disuruh mengembil bahan yang dipergunakan dan memperhatikan peragaan guru tentang bagaimana menggunakan bahan tersebut. Anak juga harus mengerjakan tugas tahap dari tahap sesuai dengan petunjuk guru. Anak yang lamban mendapat layanan khusus dari guru, dan kegiatan ini dapat berlangsung dalam jangka waktu 15 menit tetapi kemudian harus dilanjtkan dengan kegiatan lain yang berpola sama atau lain.

Kegiatan yang kreatif dilaksanak dengan cara menghadapkan anak pada berbagai masalah yang harus dipecahkan, jadi kegiatan memecahkan masalah adalah kegiatan kreatif yang sebenarnya. Dalam kegiatan belajar dengan menghadapkan anak untuk memecahkan masalah inilah yang merupakan kegiatan belajar kreatif yang sebenarnya. Pemecahan masalah ini dapat bersifat perorangan maupun kelompok. Pola kegiatan kreatif memerlukan berbagai macam sumber belajar dan media belajar yang meamdai. Fungsi guru dengan pola kegiatan yang kreatif adalah sebagai fasilitator yang selalu siap memberikan bantuan petunjuk, bimbingan, pujian, perbaikan yang dibutuhkan oleh anak. ${ }^{19}$

\section{B. Kajian Pendidkan Anak Usia Dini (TK)}

\section{Pengertian Pendidikan Anak Usia Dini (TK)}

Di dalam PP. Mo. 27 Tahun 1990 tentang pendidikan pra sekolah yang dikutip oleh dr. Soemantri Patmonodewo bab I pasal 1 ayat (2) dinyatakan bahwa yang dimaksud dengan Taman Kanak-kanak (TK) adalah salah satu bentuk pendidikan pra sekolah yang menyediakan program pendidikan dini bagi anak usia empat tahun sampai memasuki pendidikan dasar. ${ }^{20}$

Sedangkan di dalam kepurusan Menteri Pendidikan dan Kebudayaan Republik Indonesia Nomor 0486/V/1992 yang dikutib oleh

\footnotetext{
${ }^{19}$ Moeslihaton, Metode Pengajaran di Taman Kanak-Kanak , hlm. 13

${ }^{20}$ Soemantri Padmonodewo, Pendidikan Anak Pra Sekolah, (Jakarta : Rineka Cipta, 2003), hlm. 43-49
} 
beliau juga, bab I pasal 2 ayat (1) telah dinyakan, bahwa pendidikan taman kanak-kanak merupakan wadah untuk membantu pertumbuhan dan perkembangan jasmani dan rohani anak didik sesuai dengan sifat-sifat alami anak. Tidak lanjut dalam bab II pasal 4 dijelaskan, bahwa anak didik di TK adalah anak berusia 4-6 tahun. ${ }^{21}$

Dengan demikian dapat ditarik kesimpulan bahwa pendidikan anak usia dini adalah pendidikan yang diperuntukkan untuk anak usia 4 tahun sampai masuk Sekolah Dasar (SD).

\section{Tujuan Pendidikan Anak Usia Dini (TK)}

Dalam suatu proses pendidikan dibutuhkan suatu tujuan agar terlaksananya pendidikan yang lebih mengarah pada potensi dan profesi yang maksimal.Untuk mengembangkan serta meningkatkan potensi manusia (anak didik) yang pada hakekatnya telah dibawa sejak lahir, haruslah dengan cara yang baik. Dengan demikian bahwa tujuan pendidikan adalah membina dan menggerakkan seorang anak didik dalam upaya meningkatkan potensi yang dibawa sejak lahir.

Berdasarkan pertumbuhan dan kemampuan anak pada usia dini maka ada tiga tujuan pendidikan taman kanak-kanak yaitu membentuk dan mengembangkan jiwa eksploratif, membentuk dan mengembangkan jiwa kreatif serta membentuk dan mengembangkan kepribadian yang integral. Berdasarkan Undang-Undang Sistem Pendidikan Nasional disebutkan bahwa pendidikan pra sekolah bertujuan untuk mengembangkan potensi peserta didik dalam bentuk pengenalan keimanan, ketakwaan, hidup sehat, pengenalan kegiatan mandiri, nilai keindahan, peran demokrasi, peran sosial, atribut bangsa, dan lingkungan alam melalui kegiatan bermain yang menyenangkan. ${ }^{22}$

\section{Kompetensi Dasar Pendidikan Anak Usia Dini (TK)}

Berdasarkan ciri-ciri anak taman kanak-kanak, yang penuh rasa ingin tahu, senang membentuk dan memainkan benda-benda, berkeinginan meniru perilaku orang dewasa, berbagi pengalaman dengan orang lain. ${ }^{23}$

Sehubungan dengan ciri-ciri di atas maka tugas perkembangan yang diemban mereka adalah:

\footnotetext{
21 Ibid., hlm. 44

22 Theo Riyanto FIC Dan Martin Handoko FIC, Pendidikan Pada Usia Dini, (Jakarta : Grafindo, 2004), hlm. 28

23 Departemen Pendidikan dan Kebudayaan, Petunjuk Teknis Proses Belajar Mengajar di Taman Kanak-kanak, (Jakarta, 1990), hlm. 33

$260 \mid$ JURNAL LISAN AL-HAL
} 
a. Belajar keterampilan fisik yang diperlukan untuk bermain.

b. Membangun sikap yang sehat terhadap diri sendiri.

c. Belajar menyesuaikan diri dengan teman-teman sebaya.

d. Mengembangkan peran sosial sebagai lelaki dan perempuan.

e. Mengembangkan pengertian-pengertian yang diperlukan.

f. Mengembangkan hati nurani, penghayatan moral dan sopan santun.

g. Mengembangkan keterampilan dasar untuk membaca, menulis, matematika atau berhitung.

h. Mengembangkan diri untuk mencapai kemerdekaan diri.

Dalam Kurikulum Berbasis Kompetensi disebutkan bahwa hendaknya program pendidikan pra sekolah dilaksanakan melalui kegiatan bermain yang mengusahakan dan berorientasi pada pengenalan keimanan dan ketakwaan, pengenalan diri, keluarga, masyarakat, keindahan, hidup sehat dan lingkungan sekitar, dan pengenalan hidup bangsa dan peran dalam kehidupan demokrasi.

Berikut ini beberapa kemampuan TK tingkat A dan TK tingkat B: Pertama, Inventaris kemampuan dasar anak-anak TK tingkat A meliputi; a) Menguasai keterampilan untuk hidup sehari-hari; b) Mampu mengembangkan komunikasi lisan; c) Mampu membuat kalimat yang runtut; d) Mampu mengenal huruf, mengenal kalimat dalam puisi dan lagu; e) Memahami konsep matematika dalam penjumlahan dan pengurangan; f) Mampu menggunting dan menempel; g) Mampu bekerja sama dengan temannya; h) Mampu mengidentifikasikan warna lebih dari tiga warna dasar.

Kedua, Inventaris kemampuan anak-anak TK tingkat B meliputi: a) Mampu membaca, menulis, mengeja bacaan; b) Mampu menghitung dan mengukur; c) Mampu bercerita dan Tanya jawab dan memberikan alasan; d) Mengenal dan memahami aturan permainan; e) Mampu berinisiatif untuk mengubah dan membuat aturan; f) Mandiri dalam memenuhi kebutuhannya sendiri; g) Mampu bekerja sama dengan orang lain; dan h) Mampu mengenali alat dan gunanya. Oleh karena itu anak TK perlu mendapatkan rangsangan dan dukungan baik oleh orang tua dan pendukung. ${ }^{24}$

\section{Metodologi Pembelajaran pada Dimensi Perkembangan dan Kemampuan Anak Usia Dini (TK)}

Sebagaimana terdapat dalam garis-garis Besar Program Kegiatan

24 Theo Riyanto FIC Dan Martin Handoko FIC, Pendidikan Pada Usia Dini., hlm. 60

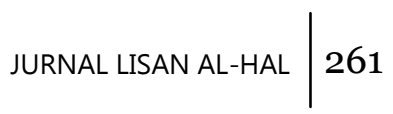


Belajar Taman Kanak-kanak, tujuan program kegiatan belajar anak TK adalah untuk membantu meletakkan dasar-dasar pendidikan ke arah pengembangan sikap, pengetahuan, keterampilan dan daya cipta yang diperlukan oleh anak dalam upaya penyesuaian diri terhadap lingkungannya, dan untuk pertumbuhan serta perkembangan selanjutnya. ${ }^{25}$

Sesuai dengan tujuan dan program kegiatan tersebut, metode yang dipergunakan berkaitan erat dengan dimensi perkembangan dan kemampuan anak dengan motorik, kognitif, bahasa, kreativitas, emosi dan sosial.26Perkembangan motorik merupakan proses memperoleh keterampilan dan pola gerakan yang dapat dilakukan anak, keterampilan motorik diperlukan untuk mengendalikan tubuh. Mototik kasar adalah korrdinasi gerakan fisik yang menggunakan obat-obat besar, seperti melompat dan menendang, sedangkan motorik halus adalah penggunaan sebagian otot kecil untuk melakukan kegiatan, seperti menggunting dan menggambar.

Perkembangan motorik sangat berpengaruh terhadap aspek-aspek perkembangan lainya. Anak yang fisiknya teraltih akan memiliki kesempatan lebih dalam mengeksplorasi lingkungan sehingga dapat lebih mengenal dan memahami lingkungannya. ${ }^{27}$ Masih ada satu lagi keterampilan anak yaitu gerakan pengamatan, maksudnya bagaimana anak melakukan gerakan dalam mengamati suatu benda. Apakah gerakan yang dilakukan itu berdaya guna, berhasil, memiliki kegunaan yang banyak, hal ini ditentukan oleh kecepatan pengamatan anak sendiri dan lingkungan sekitarnya. Karena itu, perkembangan pengamatan anak bergantung juga pada gerakan pengamatan yang dilakukan.

Dalam mengembangkan keterampilan motorik, diperlukan keterampilan mengingat dan mengalami. Anak mengingat gerakan motorik yang telah dilakukan agar dapat melakukan perbaikan dan penghalusan gerak. Pengalaman yang diperoleh anak dan keterampilan mengingat yang dimilikinya merupakan hal yang penting bagi anak dalam memperoleh keterampilan motorik tertentu. Dengan perkataan lara pengembangan keterampilan motorik memerlukan latihan-latihan, selain itu anak juga harus memiliki keterampilan dasar terlebih dahulu sebelum ia mampu memadukannya dengan kegiatan motorik yang lenih kompleks,

25 Suhaemi Adi, Pedoman Prasaran dan Sarana Taman Kanak-Kanak, (Jakarta : Departemen Pendidikan dan Kebudayaan, 1992), hlm. 1

${ }^{26}$ Moeslihaton, Metode Pengajaran di Taman Kanak-Kanak., hlm. 20

27 Edy Gustian, Mempersiapkan Anak-anak Masuk Sekolah., hlm. 7 
karena itu pula agar dapat menguasai suatu keterampilan perlu mendapat kesempatan untuk berlatih.

Metode yang digunakan adalah metode kegiatan yang dapat memacu semua kegiatan motorik yang perlu dikembangan anak, seperti menggambar untuk motorik halus dan melompat untuk motorik kasar. ${ }^{28}$ Kognitif sering kali diartikan sebagai kecerdasan atau berpikir. Kognitif adalah pengertian yang luas mengenai berpikir dan mengamati, jadi merupakan tingkah laku-tingkah laku yang mengakibatkan orang memperoleh pengetahuan atau yang dibutuhkan untuk mengkoordinasi berbagai cara berpikir untuk menyelesaikan berbagai masalah dapat dipergunakan sebagai tolak ukur pertumbuhan kecerdasan. ${ }^{29}$

Bahasa merupakan ciri paling menonjol dari cara berpikir simbolik, bahasa adalah penggunaan kata-kata untuk menyatakan benda-benda atau tindakan. Kemampuan anak dalam penggunaan bahasa merupakan indikasi diri dari kemampuan anak untuk mengolah informasi yang diterima oleh dirinya. Pada anak-anak, fungsi bahasa masih berada pada fungsi "egosentris", artinya untuk anak menggunakan bahasa untuk mengekspresikan keinginannya, seperti keinginan bermain dan keinginan makan atau memuskan rasa ingin tahunya. ${ }^{30}$

Oleh karena itu kemampuan bahasa erat hubungannya dengan kemanpuan anak maka pemilihan metode harus disesuaikan dengan tujuan kegiatan yaitu perkembangan bicara anak. Lowenfeld dan Brihain yang memiliki kreatifitas akan muncul pada diri seseorang yang memilki motivasi, rasa ingin tahu, dan imajinasi, karena mereka selalu mencari dan ingin menemukan jawaban, senang memecahkan masalah. Masalahmasalah yang ada selalu dipikirkan kembali, ingin membangun kembali, dan berusaha menemukan hubungan baru mereka, bersikap terbuka terhadap sesuatu yang tidak diketahui dan yang baru. Sikap juga lentur, tidak penurut, tidak dogmatis, suka mengekspresikan diri dan asli.

Oleh karena itu pemilihan metode yang sesuai dengan perkembangan kreatifitas anak dengan menggunakan sumber belajar yang dapat digunakan untuk merealisasi kegiatan-kegiatan yang kreatif. Menurut Gorden dan Browne emosi yang berkembang pada anak TK adalah kemampuan mengenal perasaan, baik kemampuan memberi memberi nama perasaan maupun menerima perasaan. Bagi anak TK, keterampilan yang sulit unutk dipelajari, demikian pula untuk menerima

${ }^{28}$ Moeslihaton, Metode Pengajaran di Taman Kanak-Kanak.,., hlm. 16

${ }^{29}$ Soemantri Patmonodewo, Pendidikan Anak Pra Sekolah., hlm. 27

30 Edy Gustian, Mempersiapkan Anak-anak Masuk Sekolah , hlm. 16 
perasaannya ia akan belajar bagaimana menggunakan kedalaman perasaan dan tidak mengeskpresikan secara berlebihan. Dengan mengikuti perasaan orang lain, anak TK terbantu untuk menerima dan menghargai perasaannya sehingga menumbuhkan pengertian dan kerjasama. Anak TK menikmati keadaan dan kekuatan diri sendiri. Ia memiliki perasaan bahwa dirinya dapat mengndalikan kehidupannya dan percaya terhadap kemampuannya sendiri. Oleh karena itu, pemilihan metode yang sesuai dengan pengembangan keterampilan anak harus disesuaikan dengan program kegiatan yang bertujuan mengembangkan emosi anak. ${ }^{31}$ Perkembangan tingkah laku anak dalam menyesuaikan diri dengan aturan-aturan yang berlaku dalam masyarakat dinamakan perkembangan sosialisasi. ${ }^{32}$

Hasil yang diperoleh dari proses sosialisasi merupakan keterampilan sosial yang mempunyai kedudukan strategis dalam diri anak untuk dapat membina hubungan antar pribadi dalam berbagai lingkungan dan kelompok orang. Berikut merupakan keterampilan sosial yang perlu dipelajari anak di taman kanak-kanak yaitu membina hubungan dengan orang dewasa, yaitu anak mendapat kesempatan tinggal di sekolah bersama anak lain untuk belajar menikmati dan menanggapi hubungan antar pribadi dengan anak lain secara memuaskan. Orang dewasa dapat membina saat anak membutuhkan dan mengalami kesulitan dalam menghadapi tata cara hidup bermasyarakat dan menjaga anak agar tidak menyakiti dan disakiti anak lain. Selain itu orang dewasa tidak harus selalu mendampingi dalam memecahkan masalah bila dirasakan anak mampu memecahkan sendiri.

Dalam membina hubungan dengan anak lain ada beberapa pendekatan dengan anak lain yang dilaksanakan atau tidak dapat dilaksanakan dengan keterampilan bergaul, membina hubungan, memecahkan pertentangan dengan anak lain, juga anak belajar cara yang dapat dilaksanakan dalam berbagi bahan, perlengkapan dengan anak lain atau saling mengemukakan gagasan dengan anak lain. Dalam membina hubungan dengan kelompok anak belajar untuk berperan serta dan meningkatkan hubungan kelompok antar pribadi, mengenal identitas dan belajar bekerja dalam kelompok.

Dalam membina diri sendiri sebagai individu anak belajar untuk bertanggungjawab untuk membantu diri sendiri, menjaga diri sendiri, dan berprakarsa untuk melakukan kegiatan yang dipilihnya misalnya

31 Moeslihaton, Metode Pengajaran di Taman Kanak-Kanak.,., hlm. 21

32 Soemantri Patmododewo, Patmonodewo, Pendidikan Anak Pra Sekolah.,, hlm. 31

$264 \mid$ JURNAL LISAN AL-HAL 
menyiapkan alat tulis. Anak juga belajar bekerja berdekatan dengan orang lain tanpa mengganggu.

Sesuai dengan uraian di atas, maka secara singkat dapat dikemukakan ada 4 kelompok pengembangan sosial yang dapat dipelajari anak di taman kanak-kanak yakni keterampilan dalam kaitan : membina hubungan dengan orang deawas, membina hubungan dengan orang lain, membina hubungan dengan kelompok, dan membina diri sebagai indvidu. ${ }^{33}$

\section{Simpulan}

Setelah dibahas berbagai ragam metodologi pembelajaran pada Anak Usia Dini selanjutnya akan penulis simpulkan yaitu: Pertama, Berdasarkan pertumbuhan dan kemampuan anak pada usia dini maka ada tiga tujuan pendidikan Anak Usia Dini yaitu: a) membentuk dan mengembangkan jiwa eksploratif, b) membentuk dan mengembangkan jiwa kreatif serta c) membentuk dan mengembangkan kepribadian yang integral.

Kedua, Faktor-Faktor Penyebab Banyaknya Metode Pengajaran. Menurut Prof. Dr. Winarno Surahmad, MS., berpendapat bahwa faktorfaktor yang mempengaruhi banyaknya metode mengajar adalah sebagai berikut: a) Tujuan yang berbagai jenis dan fungsinya. b) Anak didik yang berbagai tingkat kematangannya.c) Situasi yang berbagai keadaannya. d) Fasilitas yang berbeda kualitas dan kuantitasnya. e) Pribadi guru serta kemampuan profesionalnya yang berbeda. Ketiga, Metode-metode pengajaran yang sesuai dengan karakteristik anak usia TK : bermain, karyawisata, bercakap-cakap, bercerita, demonstrasi, proyek dan pemberian tugas: .Metode Bermain, Karyawisata, Bercakap-cakap, Bercerita, Demonstrasi, Proyek, Pemberian Tugas.

Keempat, Metode yang digunakan untuk membantu perkembangan bahasa anak, atau kemampuan berkomunikasi, maka guru memberi kemudahan atau peluang kepada anak dengan sebaik-baiknya. Berbagai peluang itu diantaranya sebagai berikut:a) Bertutur kata yang baik dengan anak. b) Mau mendengarkan pembicaraan anak. c) Mengajak berdialog. d) Anak dibiasakan untuk bertanya, mengekspresikan keinginannya, menghafalkan dan melantunkan lagu dan puisi.

${ }^{33}$ Moeslihaton, Metode Pengajaran di Taman Kanak-Kanak ., hlm. 23

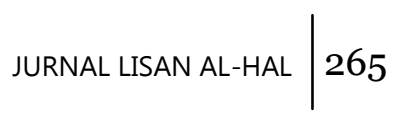




\section{DAFTAR PUSTAKA}

Adi, Suhaemi , Pedoman Prasaran dan Sarana Taman Kanak-Kanak, Jakarta: Departemen Pendidikan dan Kebudayaan, 1992

Alipandie, Imansiyah, Didaktik Metodik Pendidikan Umum, Surabaya : Usaha Nasional, 1984

Departeneb Pendidikan Nasional, Permainan Berhitung di Taman KanakKanak, Jakarta : 2000

Gustian, Edy, Mempersiapkan Anak-anak Masuk Sekolah, Jakarta: Puspa Swara, 2001

Jalaluddin Dan Usman Said, Filsafat Pendidikan Islam, Jakarta: Raja Grafindo Persada 1996

Moeslihaton, Metode Pengajaran di Taman Kanak-Kanak, Jakarta: Asdi Mahatya, 2004

Muhaimin Dkk., Strategi Belajar Mengajar, Surabaya : Citra Media, 1996

Padmonodewo, Soemantri, Pendidikan Anak Pra Sekolah, Jakarta : Rineka Cipta, 2003

Semiawan, Conny. R. , Belajar dan Pembelajaran Dalam TaraUsia Dini, Jakarta: Pranhalindo, 2002

Sudjana, Nana, Dasar-Dasar Proses Belajar Mengajar, Bandung : Sinar Baru Algensindo 1995

Surahmad, Winarno, Pengantar Penelitian Ilmu Dasar Metode dan Tehnik, Bandung : Tarsito, 1998

Syamsu Yusuf Cn., Psikologi Perkembangan Anak dan Remaja, Bandung: Remaja Rosdakarya,, 2001,

Tafsir, Ahmad, Metodologi Pengajaran Agama Islam, Bandung: Remaja Restra Karya, 2001

Theo Riyanto FIC Dan Martin Handoko FIC, Pendidikan Pada Usia Dini, Jakarta: Grafindo, 2004 